\title{
The transformation of economic analysis at the Board of Governors of the Federal Reserve System during the 1960s
}

\author{
Juan Acosta (Universidad de los Andes) and Beatrice Cherrier (CNRS-THEMA, \\ University of Cergy Pontoise)
}

\begin{abstract}
In this paper, we build on data on officials of the Federal Reserve System, oral history repositories, and hitherto under-researched archival sources to unpack the tortuous path toward crafting an institutional and intellectual space for postwar economic analysis within the Board of Governors. We show that growing attention to new macroeconomic research was a reaction to both mounting external criticisms against the Fed's decision-making process, and a process internal to the discipline whereby institutionalism was displaced by neoclassical theory and econometrics. We argue that the rise of the number of $\mathrm{PhD}$ economists working at the Fed is a symptom rather than a cause of this transformation. Key to our story are a handful of economists from the Board of Governors' Division of Research and Statistics (DRS) who did not hold a $\mathrm{PhD}$ and envisioned their role as going beyond mere data accumulation, and got involved in large-scale macroeconometric model building. We conclude that the divide between $\mathrm{PhD}$ and non-PhD economists may not be fully relevant to understand both the shift in the type of economics practiced at the Fed and the uses of this knowledge in the decision making-process. Equally important was the rift between different styles of economic analysis.
\end{abstract}




\section{INTRODUCTION}

The 2018 appointment of Jerome Powell, a trained lawyer who spend his career in finance and politics, as chairman of the Board of Governors of the Federal Reserve System is a throwback to a time when non-economists ran the "Fed." Up until the early 1970s most of the Board's governors and the presidents of the Federal Reserve Banks were not economists but bankers, lawyers, or businessmen; among the first nine chairmen, six were bankers (William Harding, Roy Young, Eugene Meyer, Marriner Eccles, Thomas McCabe, William Martin) and three had a background in law (Charles Hamlin, Daniel Crissinger, Eugene Black). ${ }^{1}$ Academic credentials were much less important than practical experience in the business and banking world, either in the private sector or at the Federal Reserve System. A successful, self-made banker with no college education like Marriner Eccles could become chairman of the Board of Governors. Since the 1960s, however, the number of trained economists serving as governors and presidents has increased substantially, and of the last Board chairmen—from Arthur Burns (1970-1978) to Janet Yellen (2014-2018)—only George Miller (1978-1979) had neither an MA nor a PhD in economics.

The postwar transformation of the Fed was not restricted to top decisionmakers. ${ }^{2}$ François Claveau and Jeremie Dion (2018) estimate that nowadays

\footnotetext{
${ }^{1}$ Note that the position of chairman of the Board of Governors exists only since the 1935 Banking Act. The pre-1935 officials named above had the position of Governor of the Federal Reserve Board. Similarly, before 1935 the Reserve Banks had governors instead of presidents.

${ }^{2}$ The Federal Open Market Committee, which presides over open market policy, consists of the seven members of the Board of Governors, the president of the Federal Reserve Bank of New York, and four of the eleven presidents of regional banks, who serve on a rotating basis. The Board of Governors sets the discount rate and reserve
} 
economists at the research departments of the Board and the Federal Reserve Banks represent nearly $50 \%$ of the money and banking economists listed by the American Economic Association (p. 353); they publish a growing share of academic papers (p. 355), and these tend to have a greater impact than those published by economists outside central banks (p. 362; see also Fox 2014, Bordo and Istrefi 2018, Ban 2018). This closer relationship between central banks and academia has been interpreted by historians and sociologists as contributing to a "scientization" of central banking, a "process by which explicit, abstract, intellectually calculable rules and procedures are increasingly substituted for sentiments, tradition, and rules of thumb" (Wrong 1970 quoted in Marcussen 2009, p. 375). Similarly, protagonists generally agree that the 1960s were a pivotal moment in the march toward a more modern and technocratic institution (Maisel 1973, Stockwell 1989; Axilrod 2011; Meltzer 2010). ${ }^{3}$ How this transformation was engineered, by whom, and how it unfolded, however, remain a blind spot of the flourishing literature on central banking. This paper is a contribution to the understanding of the early stages of this transformation.

Histories of the Fed span several genres. One, mentioned above, is popular among sociologists, political scientists and international relation specialists. It deals with how central bankers have shaped the postwar social, economic, and financial international order, and how the institutional and legal foundations of their operations requirements. Throughout this paper, we will use "Fed" to designate the Federal Reserve System as a whole, and the Board and the FOMC respectively to designate the two bodies who set monetary policy.

${ }^{3}$ See also Schnidman and MacMillan (2016), who rely on an interview with Stephen Axilrod, a former staff member of the Board. 
have been transformed (Ban 2018; Lebaron 2012; Baker et al. 2017; McGregor and Young 2013). In these works, the economic identity of major protagonists matters in that it structures their policy views and agency; their contribution to economic knowledge is secondary. The focus is not on the models they build and test, nor on their controversies, but on how they vote as members of the Federal Open Market Committee (FOMC). Neither are economists qua scientists central in the works of economic historians, whose objects are the monetary policies implemented by central bankers (Bordo 2008; Feiertag and Margariaz 2016; Hetzel 2008; Monnet 2014; Wood 2005). Even Allan Meltzer's history of Federal Reserve (2003; 2009), despite its detailed discussions and broad coverage, discusses only changes in the tools and practices of economic analysis briefly, as accessories to a story centered mostly on the Fed's policy actions.

On the opposite side of the spectrum, historians of economics portray macroeconomists and monetary economists as model builders (Hoover 1990, De Vroey 2016; Snowdon and Vane 2005), while paying little or no attention to their connections with central banks. Exceptions to this separation between institutional and intellectual histories are Conti-Brown (2017) and Mehrling (2010), but these works are more specific in scope: they are concerned with the history of the central bank's independence and dealer of last resort ideas respectively. Similarly, participants narratives have pointed out the connection — or disconnection-between academic macroeconomics and economic analysis at the Fed (Mankiw 2006; Woodford 2009), but these views are embedded in a larger discussion about the virtues and vices of the discipline that deals only marginally with the developments at the Fed itself. 
A final popular genre is biographies and autobiographies: Bernanke's (2015) memoirs is only the last one of a series that includes reminiscences by Maisel (1973), Axilrod (2011), Stockwell (1989), Mallaby's 2016 prize winning biography of Alan Greenspan, and Bremner's 2004 landmark biography of chairman William McChesney Martin. They provide lively daily accounts of the intellectual climate, the debates, and the types of work economists were tasked with at the Fed, but information on why they were hired in the first place, allowed to research and build models, and challenged has to be extracted and reconstructed from their memories. ${ }^{4}$

In this paper, we build on data on Fed officials, oral history repositories, and hitherto under-researched archival sources to unpack the tortuous path toward crafting an institutional and intellectual space for postwar developments in theoretical and empirical macroeconomics within the Board of Governors. We argue that growing attention to new macroeconomic research and practices at the Board during the 1960s was the combined result of the mounting external criticisms of the Fed's decisionmaking process, an internal push for quantification, and the staff's interest in macroeconometric modeling. This transformation in the type of economic analysis produced and used at the Board fits to some extent the oft-described process internal to economics, whereby mathematical and econometric modeling displaced previous forms of analysis (Morgan Rutherford 1998). However, while the development of new practices at the Board's Division of Research and Statistics (DRS) did involve a break with the existing economic traditions at the Board, the result was not a takeover by the new techniques and practices of academic economics. Instead,

\footnotetext{
${ }^{4}$ Maisel (1973) includes a whole chapter on the introduction of forecasts at the Fed in the 1960s, but it focuses on the uses rather than the making of economic knowledge.
} 
macroeconometric modeling integrated with a longstanding tradition of judgmental analysis, which continued to play the main role in the production of forecasts throughout the 1960s. And, although forecasts and alternative scenarios became regular inputs for the FOMC meetings in the form of the Greenbook and the Bluebook, the policy-making process was not drastically altered. Finally, we conclude as well that the rise of the number of $\mathrm{PhD}$ economists working at the Board's staff is a symptom rather than a cause of this transformation. Furthermore, the variety in the staff's training (in terms level of education, period, and university) suggests that the divide between $\mathrm{PhD}$ and non- $\mathrm{PhD}$ economists may only be partially relevant to understand both the shift in the type of economics practiced at the Board and the uses of this knowledge in the decision making-process during this period.

\section{THE FED UNDER PRESSURE}

William McChesney Martin, chairman of the Board of Governors of the Federal Reserve System between 1951 and 1970, took office in April 1951. A month earlier, as assistant secretary of the Treasury, he had negotiated a landmark agreement between the Treasury and the Fed (Hetzel and Leach 2012). The March 4, 1951 accord officially ended the peg on interest rates that the Fed had maintained since 1942 as part of the war effort, and Martin was therefore eager to reassess the Fed's newfound ability to pursue independent monetary policy. Throughout his tenure Martin worked to distance the Fed from the political pressures of Washington and to make the Board of Governors the center of the Federal Reserve System—thus reclaiming the spot from the Federal Reserve Bank of New York, which Martin considered to be too close to the financial community (Meltzer 2009, p. 55ff). By the end of the 1950s, however the Fed faced mounting criticisms from governmental 
bodies, the financial community, congressional committees, and the press. ${ }^{5}$ The Council of Economic Advisers sent weekly memos to Kennedy complaining about high interest rates (Cherrier 2018); the Joint Economic Committee of the Congress published a critical 1959 report largely authored by Otto Eckstein, and two more followed in 1960; the Commission on Money and Credit issued its report in 1961; and Wright Patman's Committee on Banking and Currency carried out a series of hearings in 1964. The Fed's policy orientations, as well as the decision process which led to them, were disparaged on a daily basis. Though sometimes highly political, most of these attacks were also fueled by academic economists who essentially faulted the Fed for not relying on economic science to guide their policymaking.

\section{Dissatisfaction with policy orientations}

A first line of criticisms targeted the Fed's policy choices. James Knipe, a special consultant to the Board's chairman, wrote a digest of "the public criticism of the Federal Reserve system" for Martin in 1962. He explained that monetary policy was

\footnotetext{
${ }^{5}$ Maisel (1973, pp. 27-29) describes some of these pressures. New economic phenomena, in particular mounting inflation from 1966 onward and the deterioration of the Bretton Woods system added to the challenges.

${ }^{6}$ The Commission was established by the Committee on Economic Development, a nongovernmental institution focused on public policy research. Members of the Commission included Marriner Eccles, Adolph Berle, David Rockefeller, Theodore Yntema. The research director was Harvard's Betrand Fox and his deputy MIT's Eli Shapiro. Lester Chandler, Paul Samuleson and Sumner Slichter, among others, had joined the advisory board. See Knipe (1962) and Brunner (1961)
} 
seen as lacking effectiveness in controlling expenditure on capital equipment and business inventories, but was "too effective" in restraining residential construction, public projects, and small businesses (Knipe 1962, p. 20). In addition, critics considered that the Fed was "stunting national economic growth" by maintaining interest rates too high, and that this was the consequence of the undue influence of private banking interests (p. 64). These criticisms focused on the choice of targets as well as the choice of instruments.

\section{President John F. Kennedy’s Council of Economic Advisers (comprising} Minnesota tax expert Walter Heller, Yale macroeconomist James Tobin, and budget specialist Kermit Gordon) was especially outspoken with regard to the choice of targets. They flooded the president with memoranda explaining that "monetary policy has made no significant contribution to economic recovery." "Short-term rates have been kept from falling to protect our gold stock," they complained. ${ }^{9}$ Tobin, whose research stood at the frontier of monetary economics, was even willing to go public. In January of the same year, he published a vocal critic of the Fed in Challenge, a magazine specialized on public policy. He warned about building tensions between the Fed and both the administration and Congress on inflation, growth, and the management of the debt. The essential problem was the price stability fetish at the Fed: "the heavy reliance placed on monetary restraint over the past eight years is one of the reasons that, relative to GNP, consumption has grown while investment has fallen," he explained (Tobin 1961, p. 26). He also condemned the Fed's belief that deviating from monetary restraint would result in a "collapse." "[T]he economic logic

\footnotetext{
${ }^{9}$ CEA to President, "Monetary Policy: High Time for Action,” April 6, 1961. JFKA.
} See also the comments reported by Bremner (2004, p. 150) 
of this prejudice [was], to say the least, obscure," he chaffed (p. 26). Tobin did not merely fault the Fed for its narrow economic target, but also for rejecting the idea that price stabilization could be achieved by a combination of easier monetary policy and fiscal restraint. He also denounced the Fed's neglect of the cost of the debt for the Treasury when choosing the combination of reserve requirements and open market operations used throughout the business cycle (Tobin 1961, p. 27).

In a study commissioned by the House Committee on Banking and Currency, Karl Brunner and Alan Meltzer (1964a,b,c) instead criticized the Fed's use of free reserves as an indicator of the degree of liquidity of the market and of individual banks, and its failure to distinguish between individual banks and system-wide changes on free reserves. In line with future monetarist precepts, they argued that "[t]he desired growth rate of the money supply should be explicitly chosen for a 6month or longer period and policy operations should be directed towards achieving that growth rate by explicit choice of a growth rate for the monetary base" (1964c, p. 84).

\section{Dissatisfaction with the Fed's policy decision-making process}

These economists also criticized how the Fed arrived at its policy decisions. Brunner and Meltzer (1963a, p. viii) made it clear that it was their main concern: "we believe that there is a more important series of questions that has not been asked very often: are the procedures for making monetary policy adequate? Does the Federal Reserve have adequate information in sufficient time to make appropriate decisions?," Brunner and Meltzer stated at the beginning of their study. First, they found the 
decision-making process plagued with short-term thinking. The FOMC met every three weeks, which was too often, led them to focus too much on short-run phenomena, and to rely on the "tone and feel" of the market rather than serious quantitative analysis. Second, the FOMC was monitoring too many variables, reflecting vague and contradictory definitions of concepts like "credit" and “availability.” Brunner and Meltzer identified "a variety of magnitudes or entities reflecting the behavior of banks or the operations on credit markets ... some refer to free reserves, some to short-term rates; others point to reserves, required reserves, 'credit,' long-term yields, short-term yields, liquid assets" and concluded that "the very mixed nature of these criteria reveals the absence of a coherent conception" (1964a, p. 4).

Short-term thinking and lack of structure resulted in a lack of direction, Brunner and Meltzer concluded, echoing other critics. A specific longstanding bone of contention was the content of the directive that the FOMC issued to the manager of the Fed's Trading Desk—located at the New York Fed—to implement open-market policy. The directive was initially loose, of the "ease or restraint" type. This left a huge discretionary power to the New York Fed, which early on Martin attempted to reduce. How to draft a more specific directive was discussed and re-discussed throughout the 1960s and 1970s. This "indecision" also stemmed from the absence of real debates and confrontation of alternative frameworks. While active and at times "heated" discussions took place during FOMC meetings, these did not necessarily "contribute to the formation of rational monetary policy ... [as a] variety of unsubstantiated judgments and unsupported opinions replaces analysis and evidence as the basis for policy operations," Brunner and Meltzer (1964c, p. 92) bemoaned. 
Their suggestion for reform was consequently radical: "serious consideration should be given to replacing the FOMC with a single administrative official," they wrote (p. 93).

Another line of criticism was the Fed's lack of transparency. Both the Joint Economic Committee and the Monetary Commission complained that the lack of communication of the reasons for the Fed's major policy decisions and actions resulted in "a tendency to seize upon even the most outlandish rumors as significant" (Knipe 1962, p. 40). There was however, a more fundamental attack behind the demand for transparency. The key issue, highlighted by Tobin in his Challenge article, was how the Board had used its freedom since 1951. The independence of the Fed had become a "heated issue, a symbol of irresponsible power to some, and to others the last citadel protecting the dollar and the country from disaster," Tobin (1961, p. 24) noted.

Thwarting this newfound independence was precisely the agenda of the chairman of the House Committee on Banking and Currency, Texas congressman Wright Patman. Dubbed "the populist scourge of the Fed," he was a staunch opponent of high interest rates and of the separation of monetary and fiscal policy, which he constantly challenged after 1951 (Conti-Brown 2017, 274-276; see also Young 2000, ch. 7,8$)$. In 1964, he proposed to hold four months of hearings for the $50^{\text {th }}$ anniversary of the 1913 Federal Reserve Act (Congress 1964), hoping that the Congress would eventually agree to get rid of the FOMC, reduce the budgetary autonomy of the Fed, and restore the primacy of the Treasury regarding the definition of monetary policy. President Lyndon Johnson's intervention, at Martin’s request 
(source ??), thwarted Patman's plans, but the criticisms outlined in the BrunnerMeltzer report, commissioned by the Committee, would have a lasting influence. Again, the report echoed the 1959 diagnosis of the Joint Economic Committee: monetary and fiscal policy should be better coordinated, under the oversight of the executive or the Congress (Knipe 1962, p. 32). It was suggested that either the chairman of the CEA or the Secretary of the Treasury sit on the Board of Governors.

\section{Dissatisfaction with the lack of scientific underpinnings}

Underlying these criticisms of monetary policy was thus the shared notion that "after 50 years the Federal Reserve ha[d] not yet provided a rational foundation for policymaking” (Brunner and Meltzer 1964a, p. ix). For those policy-oriented yet academic economists involved in monetary debates, "rational foundation" meant science-based. Brunner and Meltzer were explicit that the Fed "should develop and test a theory incorporating the essential elements of the money supply process" (1964c, p. 83). This insistence on solid theoretical and empirical foundations echoed almost verbatim Tobin's earlier complaint that the Fed's decisions "rel[y] more on a general faith that virtue pays than on careful empirical and theoretical analysis" (Tobin 1961, p. 26; see also Maisel 1973, p. 168).

Monetary theories were being hotly debated at the time and consensus was rare. Economists did not agree on the channels whereby monetary policy influenced the real economy, and hence they could not agree on the adequate instruments for 
policy. ${ }^{10}$ For Brunner and Meltzer (1964a, pp. 2-3), however, the lack of consensus was not an issue. It was the competition between rival yet scientifically informed conceptions of monetary policy that would create rational policy decisions. The confrontation would be solved through discussion and empirical testing, academic economists insisted. What the Fed needed was a systematic framework for “continuous appraisal, reappraisal and comparison [of] alternative conceptions."11 The problem, they argued, was not that the Fed lacked in-house research facilities, but that it was not doing the right kind of science. The Board had a Division for Research and Statistics (DRS) and the Federal Reserve Banks were also staffing up their research departments. But these bodies were largely devoted to the collection of data on banks and credit markets, which explained the Fed's excellent record in identifying the turning points of the business cycle—which even Brunner and Meltzer acknowledged (1964a, p. viii). "But the relevance of this mass of data cannot be judged in the absence of a coherent conception systematically weaving this information into a meaningful pattern," Brunner and Meltzer (1964a, p. 3) claimed. "Collection and preparation of data not guided by an explicit analytical frame often leads to a pointless accumulation of data" (p. 3). ${ }^{12}$

\footnotetext{
${ }^{10}$ As a contemporary observer, surveying the Fed's official views on monetary policy, noted that "the past decade has witnessed a resurgence of controversy over the perennial issues of monetary policy. What methods should it employ? What are the channels or processes through which it influences economic activity? By now, opinion has become so sharply divided...as to almost defy classification" (Ritter 1962, p. 14).

${ }^{11}$ Franco Modigliani and Milton Friedman made similar remarks to the Board in 1965, see Rancan (2019).

12 The accusation of "pointless accumulation of data" echoes the "Measurement without theory" debate, prompted by the scathing review of NBER's Arthur Burns and Wesley Mitchel's Measuring Business Cycles (1946) published by the Cowles Commission's Tjalling Koopmas (1947). See Morgan and Rutherford (1998), Mirowski (1989), and Rutherford (2011, ch. ??) for a discussion of this
} 
It would have been very difficult for Martin, the Board, and the Fed in general to ignore their critics. Economists who would otherwise disagree on most of their views agreed on their criticism of the Fed, and their arguments were powerful ammunition for the those in Congress that constantly threatened the Fed's independence. ${ }^{13}$ What to do, however, wasn't clear, for staffing up and giving greater agency to economists could create new questions and divisions. Inside the Board, as elsewhere in economic circles, the two linked debates over the quantification of economic variables and relationships, and the relative merits of inductive vs deductive empirical analysis played out full volume.

\section{INSIDE THE BOARD}

A year after leaving the Board, former Governor Sherman Maisel clearly outlined the mid-1960s ethos: "the Fed found itself on the defensive. Specific accusations of bad judgment could no longer be countered by generalities. The system had to develop a more comprehensive theory of monetary policy and clarify its own views" (Maisel 1973, p. 26). Martin was acutely aware of these external pressures. Furthermore, the composition of the FOMC and the Board's staff was shifting in these years, which resulted in growing divides on how the Fed should respond.

controversy. Brunner's criticism of pure data gathering, however, must not be taken to be an endorsement of the Cowles Commission approach to the relationship between theory and empirics. See Hoover (2018) for a discussion of Brunner's approach to empirical work.

${ }^{13}$ As former Governor Sherman Maisel pointed out, Patman "always had a bill to do away with the powers of the Fed. There was a general recognition that you had to handle the Congress in such a way that Patman wouldn't get his way" (2009, p. 27) 
Changing views of monetary policy-making at the FOMC

Kennedy and Johnson were, Heller reflected after completing his term as chairman of the Council of Economic Advisers, "the first modern economists in the American presidency" (Heller 1967, p. 37). Tables 1 and 2 in the apendix display the consequences of these presidents' inclination towards economics: four of the five Governors whom they appointed were economists, and three of them had PhDs. Kennedy's first appointment was George Mitchell (app. 1961), a tax economist with a BA from the University of Wisconsin and who at the time was the vice president of the Federal Reserve Bank of Chicago. A handful of economists had served as Governors before, but the first economics $\mathrm{PhD}$ had been appointed by Eisenhower in 1955. Canby Balderston (app. 1954), aged 57 at the time of his appointment, had a $\mathrm{PhD}$ from the University of Pennsylvania (1928) and was the Dean of the Wharton School of Finance and Commerce at the time. ${ }^{14}$ After Mitchell, who was also 57 when he was appointed, Kennedy and Johnson, subsequently appointed three younger economists, all of them trained at Harvard as the Keynesian revolution was being absorbed in graduate curricula: James Dewey Daane (app. 1963), who graduated in 1949 with a doctorate in public administration, ${ }^{15}$ had previously worked at the Federal

${ }^{14} \mathrm{We}$ are excluding here Paul E. Miller, who served as Governor for two months during 1954, was a trained (BS, MSc) in agriculture, and received the honorary degree of Doctor in Economic Science from the University of Ireland in 1951.

${ }^{15}$ His dissertation was, nonetheless, listed in the 1949 AEA's list of doctoral dissertations in political economy. It is also noteworthy that Daane, a Fed insider supported by Martin, was not the first choice. The Treasury wanted Seymour Harris, a whose priorities aligned more with the Kennedy's administration (Daane 2006, p. 14). 
Reserve Banks of Richmond and Minneapolis as well as the Treasury; Sherman Maisel (app. 1965), who also graduated in 1949, was a professor at Berkeley; and Andrew Brimmer (app. 1966), who became the first African American to serve on the Board, had graduated in 1957, then worked at the New York Fed and the US Department of Commerce.

The tables 3 and 4 list information on the presidents of the Federal Reserve Banks from 1950 through the mid 1970s. When Martin was appointed as chairman there was only one president with a PhD, Alfred H. Williams (Pennsylvania, 1924). The other presidents were professional bankers that had climbed the ladder in the private sector or made a career at the Federal Reserve System. For example, New York Fed's Allan Sproul, who became a widely recognized master of the art of central banking, had originally studied pomology at Berkeley and had started his career at the Fed as head of the San Francisco Fed's Division of Analysis and Research despite knowing "little about banking and nothing about central banking" (Sproul quoted in Ritter 1980, p. 4). By the time Burns was appointed chairman of the Fed in 1970, however, there were five PhDs serving as presidents of Federal Reserve Banks, and by 1975 they had become a majority.

Being trained in economics was, however, increasingly seen as a prerequisite for sound policy-making decisions. The kind of career chairman Marriner Eccles (1934-1948) built after taking over his father's businesses right after high school was becoming an exception. And the fact that Martin himself - a banker and former president of the New York Stock Exchange_-had no background in economics was 
increasingly pointed out. ${ }^{16}$ The CEA staff often complained about his lack of economic expertise. For instance, Gardner Ackley, who replaced Heller as CEA chairman, later remarked that "Martin was absolutely zero as an economist. He had no real understanding of economics" (Ackley 1974, p. 5; see also Maisel 1973, p. 122123). This momentum contributed to the nomination of Arthur Burns, whose work on business cycles was widely recognized, as chairman in 1970. Of him Ackley said: "[he] is a first-rate, intelligent economist. He talks about things much in the same terms that I do; and even if we often disagree, at least there is communication at a professional level" (Ackley 1974, p. 11).

Martin lacked academic credentials in economics, but he supported the Board's interaction with economists. In 1964, he complained to G.L. Bach that "[t]he Board feels that ... it ... has not had very effective contacts with academic economists on monetary issues" and asked him to organize an "Academic Consultant Meetings" series akin to what Seymour Harris had set up at the Treasury in $1960 .{ }^{17}$ The founding director of the Carnegie School of Industrial Administration, Bach activated his wide network to invite some of the most renowned macroeconomists: Stanford's Edward Shaw, Yale's James Tobin, Harvard's James Duesenberry, and Massachusetts Institute of Technology's Franco Modigliani, among others, participated in the first meeting. Milton Friedman visited the Board a few weeks later, and he and Meltzer

\footnotetext{
${ }^{16}$ Bremner $(2004,24)$ reports that he started a $\mathrm{PhD}$ in finance at Columbia in 1935 , although he did not graduate.

${ }^{17}$ Bach to Modigliani, dated November 15, 1953, but the year is a typo, it was written in 1963. FMA. See Also Martin to Modigliani, February 4, 1964.
} 
participated in future meetings, which became a regular event, taking place at least once a year from then on. ${ }^{19}$

At the same time, even if the academically trained members agreed that there was more to monetary policy than a scientific framework, the shift in the FOMC's demographics created a rift between "two bands: younger, Keynesian-laden staff vs traditionalists" (Maisel 1973, pp. 215-216). Maisel relentlessly fought for the inclusion of new indicators and formal forecasts in FOMC deliberations (Bremner 2004, p. 253), and Mitchell enthusiastically pushed for the dissemination of empirical research, declaring that by 1967, "the 'new economics' was firmly in the saddle" at the Board. ${ }^{21}$

${ }^{19}$ Bach to Modigliani, 01/08/1964. Topics included "lags and signals for monetary action," "the demand-time deposits mix problem" or "the quality of credit problem." Modigliani's papers include material from academic consultants meetings up to the early 1980s. G. L. Bach remained the organizer.

${ }^{21}$ Bremner (2004, p. 230n18). Holland to Modigliani, 01/20/64. The push for quantification did not mean that the new economists at the Board disregarded the complexities of monetary policymaking. Maisel, one of the staunchest supporters of quantification, acknowledged that "[b]efore my appointment to the Board of Governors of the Federal Reserve System in 1965, I had spent nearly twenty years studying and teaching monetary economics. I thought I understood what the Fed did and how it affected the economy. I soon discovered how little I knew" (Maisel 1973, p. ix). 
It was not just that the older bankers assembled around Martin did not catch on this intellectual renewal. They actively rejected their younger colleagues' push for quantification and rationalization. Martin believed that financial markets were characterized by uncertainty and complex psychological individual and collective phenomena, so that he had very little faith in the value of attempting to quantify Federal Reserve policy. In his opinion, measurement was dangerous, if not impossible: numbers obtained would not accurately reflect real conditions and the Fed could do best by carefully evaluating events in the financial markets (Maisel 1973, p. 118). The chairman had to be skilled in reading the "tone and feel" of the market, and all his colleagues concurred that Martin was exceptionally gifted in the matter. Maisel (1973, p. 170) again aptly summarized Martin's paradoxical stance:

Chairman Martin led the group who felt that Federal Reserve policy had to remain an art rather than a science. However, while he opposed the introduction of any specific analytical framework, he did believe in research and knowledge. He allowed and even encouraged the staff to explore new techniques, but at the same time he adhered to his belief that real quantification was impossible, that it would downgrade judgment and intuition, and therefore would lead to greater errors on the part of the Federal Reserve.

It was thus that by the mid sixties, aided by the enthusiasm of the economist governors, and allowed by a suspicious but permissive chairman, a space was opening at the Board for new forms of economics analysis to enter the policymaking process. 
It would be up to the Board's staff, by then already in close contact with the latest developments in academic macroeconomics, to widen and this space.

\section{The Board's Division of Research and Statistics}

Unlike the Board of Governors and the FOMC, the Division of Research and Statistics (DRS) had hired and been directed by economists since its establishment in 1918. ${ }^{22}$ Since the DRS is less visible than the FOMC, systematic information is more difficult to gather. Tables 5 and 6 provide background information on DRS topadvisors up to $1975 .{ }^{23}$ They show no overwhelming trend toward an academicization of the DRS akin to what is visible within the FOMC, but rather the continuation of a pre-war trend: $47 \%(8 / 17)$ top DRS officials who had been recruited in the preMartin era held a $\mathrm{PhD}$, and by the end of Martin's tenure the number had risen to $65 \%$ (13/20). There was, however, more diversity among PhD programs than at the FOMC, which was dominated by a Harvard pipeline.

22 The DRS resulted from the merging of the Office of the Statistician and the Division of Analysis and Research in 1923. It was not the only one that carried out research. The Division of International Finance also hired economists and carried out research. We have left the DIF out of the picture, because the intellectual context for its operations - international economics - has hitherto been less researched. Also, the academic and professional communities involved were slightly different. See Yohe (1990) for a discussion of research at the Board in the 1920s.

${ }^{23}$ These include associate and assistant directors, advisers, and assistant and associate advisers. 
These tables also highlight other interesting evolutions. First, assuming the number of top officials is positively related to the total size of the DRS, the latter had substantially grown in size, which in turn suggests its role had expanded within the Fed. In the fifties, the number of top officials grew from four to eight, then remained stagnant in the first half of the 1960s. In the wake of external challenges to monetary policies, the DRS head was staffed up to 14 in 1970 and 18 by March $1975 .{ }^{24}$ Second, with the exception of Ralph Young (dir. 1949-60) and Arthur Marget, who were directly hired in top positions, and Guy Noyes (dir. 1960-3), whose promotion was expedited, new recruits climbed the ladders within the DRS. Before 1960, reaching a top position took an average of sixteen years. For those hired after 1965, it only took 5.4 year on average, meaning that DRS top officials were considerably younger by the time Martin resigned. Finally, a sizeable number of these economists obtained a PhD while working at the DRS. They were thus presumably more in touch with recent advances in monetary economics than the previous generation of top officials. Table 8 shows that some of the early DRS economists completed it ten to fifteen years after recruitment; for the later period most got their PhDs a couple of years after entering the Fed, which most likely means they were hired right after finishing their coursework. This challenges the usual separation between academic economists and practitioners (or central banking economists).

\footnotetext{
${ }^{24}$ We don't have detailed information about the size of the staff employed at the DRS at all points in time during the 1960s. In 1966, however, Brill reported that of the "approximately" 180 members of the DRS, "about" half were economists or senior research assistants, "the bulk" of which carried out "current analysis and/or more basic research projects" and "about" a third worked on maintaining key time series. Brill to Brimmer, March 8, 1966, p. 1, AFBP.
} 
Counting PhDs, however, oversimplifies the transformation that took place at the DRS during the 1960s. Oral histories ${ }^{25}$ and personal archives show a more complex story, in which a transition between different styles of economic thinking was taking place. Many DRS directors had strong connections to the institutionalist movement, starting with Walter Stewart, a former professor at Amherst College who had also worked with Wesley Mitchell (Yohe 1990; Rutherford 2011, ch. 6). ${ }^{27}$ Woodlief Thomas had graduated from the Brookings Graduate School (Rutherford 2011, ch. 7), and Ralph Young had been the director of the NBER's Financial Research Program before entering the DRS..$^{28}$ Finally, Daniel Brill, director throughout much of the 1960s, initially entered the DRS as Morris Copeland's main

25 There are two major collections of oral histories. First, there's Robert Hetzel's oral history collection, which comprises interviews carried out between 1994 and 2003. It is available online at https://fraser.stlouisfed.org/archival/4927. Second, this year the Board released its oral history project, carried out to commemorate the centenary of the Federal Reserve's establishment. Interviews are available online at: https://www.federalreserve.gov/aboutthefed/centennial/federal-reserve-oral$\underline{\text { history-interviews.htm }}$

${ }^{27}$ In fact, it was Mitchell who recommended him for a position at the Fed (Yohe 1990, p. 470).

${ }^{28}$ See the Federal Reserve Bulletin for a short profile of Young (March, 1967, 388). See Saulnier (1947) for a description of the Financial Research Program. Young stayed at the Board for a few more years as adviser to the Board and as director of the Division of International Finance after he left the DRS. 
assistant in his project to build the first flow-of-funds accounts in the late 1940s. ${ }^{29}$ Key to the DRS mission was thus the data intensive approach several directors had inherited from their contact with the Mitchell-NBER research agenda.

And yet, it was Daniel Brill, who had been trained before the war, did not have a $\mathrm{PhD}$, and had a deep connection to American Institutionalism through his work with Copeland, who became a pivotal figure in the DRS's endorsement of macroeconometric during the 1960s. ${ }^{30}$ In 1960 he was asked by the recently created Committee on Economic Stability of the Social Science Research Council (SSRC) to participate in their macroeconometric model project. The purpose of the Committee was to develop a larger version of the kind of multi-equation representation of an economy initially developed by Jan Tinbergen before the war and then adapted to the US economy by Lawrence Klein in a Keynesian framework. The team of more than 20 researchers, led by Klein and Duesenberry, wanted to reach a wider degree of disaggregation, and entrusted various participants with writing blocks of equations meant to describe aggregate consumption, investment, the financial sector, the

${ }^{29}$ See the Federal Reserve Bulletin for a short profile on Brill (December, 1963, 1653-4) and Copeland's recommendation letter for the Rockefeller Public service Award, October 21, 1953. On Copeland, see Rutherford (2011, ch. 4).

${ }^{30}$ Brill did do some graduate work at the American University in Washington in 1937-38 but didn't get a PhD. Similarly, the AEA dissertations list shows that Guy Noyes, the DRS's previous director, attended graduate school at Yale but also did not graduate. 
housing sector, among others. ${ }^{31}$ Brill, then an associate advisor of the DRS, had been selected as the expert in charge of the financial sector of the model, but early on DRS economist Frank de Leeuw took over Brill's work and wrote the published version of the financial sector for the Committee's model (De Leeuw 1965). ${ }^{32}$ Although Brill did not contribute directly to the modeling work at the DRS, he supported it throughout his tenure as director and is remembered by the former staff as having played a major role in the transformation of the staff and the type of economic analysis carried out at the Board. ${ }^{33}$

Frank de Leeuw joined the San Francisco Fed in 1953, the same year he obtained a Master's in Public Administration from Harvard, and transferred to the DRS in 1956. His initial work was on the demand for capital goods, but his work for the SSRC in the early 1960s led him to specialize in monetary economics. In 1964 he took a nine month leave of absence to comply with the residency requirements for a doctorate at

31 This depiction of the SSRC Committee and their macroeconometric model project relies on Acosta and Pinzón-Fuchs (2018). See Pinzón-Fuchs (2017) for a discussion of Klein's approach to macroeconometric modeling, and Bodkin et al. (1991) for a survey of macroeconometric modeling in the US and the importance of the SSRCBrookings model.

${ }^{32}$ Sherman Maisel was the expert in charge of the non-industrial construction sector of the model. See list of experts, SSRC1, and Acosta \& Pinzón-Fuchs (2018) for more details.

${ }^{33}$ Edward Ettin (2006, pp. 3-4) credits Brill with starting a change towards "a culture where people were seriously interested in economics and were respected for what they were able to do on the economic side." See also Gramley (2007, p. 5), Enzler (2013, p. 35), Kichline (2007, p. 5), Gramlich (2007, p. 2), and Meltzer 2009, 493. 
Harvard. His dissertation (De Leeuw 1965b) comprised his work for the Committee's model (De Leeuw 1965a) and additional simulation work he had published the year before (De Leeuw 1964). Under the "general direction of Daniel Brill" (1965a, p. 465n1), De Leeuw had crafted a nineteen-equation model spanning seven financial markets and five groups of agents. It was considerably larger and more disaggregated than any previous depiction of the financial sector, and allowed useful simulation experiments by including explicit parameters for actual monetary policy instruments — such as unborrowed reserves or reserve requirements on demand and time deposits. It also presented an early implementation of a portfolio choice framework of behavior for all the financial agents included in the model (Acosta and Rubin 2019). The dissertation — which shared the title of his chapter for the Committee's model, “A model of financial behavior”- was defended in June 1965 and signed by Duesenberry and John Lintner, but De Leeuw also thanked his colleagues at the DRS and at the Committee model project. His work thus fully represented a synthesis between academic debates and central bank research.

If Brill was the administrative supporter, De Leeuw was the key driving force behind the development of macroeconometric expertise at the DRS. "All the young people at the Fed then felt he walked on water," Edward Gramlich (2004) remembers. "In the back rooms of the research division, experimental work with the new science of econometric modeling was going on. This was mind-stretching work for Frank de Leeuw and the rest of the staff involved," Stockwell (1989, p. 22) likewise describes. ${ }^{34}$ The push was supported by the establishment of an empirical seminar by Martin

${ }^{34}$ See also Gramlich (2007, p. 2) andStockwell (1989, p. 22). Patric Hendershott, who worked with De Leeuw at the DRS during 1964-1967 considers he got "a 
and DRS associate director Robert Holland in $1964 .{ }^{35}$ It was also enabled by the arrival of computers to the Board, which had a mainframe computer since at least the late 1950s, and in 1963 established a Division of Data Processing. ${ }^{36}$ Computer facilities seem to have been less than ideal in the 1960s and even throughout the 1980s, according to former DRS associate director Jared Enzler (2013, p. 17). They were initially used mostly for the production of statistics, and econometric modelers would had to patiently wait for their turn or buy computer time outside of the Board (pp. 6-7). Still, the Board had software for multiple regression analysis and a devoted staff also wrote additional FORTRAN programs to suit its needs. ${ }^{38}$

The work of Brill and De Leeuw was supported by the two successive directors of the DRS, Ralph Young (1949-1960)—who stayed as secretary of the FOMC afterwards - and Guy Noyes (1960-1963), and this might have been the most significant transformation. Throughout the 1950s, the work of the DRS had been shackled by the vision of the assistant to the chair and secretary of the FOMC

second PhD" by working with him (Telephone conversation with Juan Acosta, August 13, 2019.

${ }^{35}$ Holland to Modigliani, 02/04/194, ibid.

${ }^{36}$ Board Minutes and Federal Reserve Bulletin, 1962, October, p. 1291.

${ }^{38}$ The July 15 and August 23, 1963 issues of the Newsletter of the Committee on Computers in Research, Federal Reserve System present Ann Walka's work on a program to carry out transformations of variables. Some issues of the Newsletter are available at http://www.emelichar.com/ProgrammingNote.html. Walka did all the computer work related to De Leeuw's work on the financial model up to 1965. Enid Miller, a programmer, and Helen Popkin also worked with De Leeuw in the second half of the 1960s. 
Winfield Riefler. A graduate of the Brookings Graduate School (Rutherford 2011, ch. 7), Riefler had a strong influence on Martin, Board members, and the staff thanks to his "persuasive intellect," a 1964 article from Business Week recounts. ${ }^{40}$ He had established a "Riefler rule" whereby the Federal Reserve "didn't make or discuss forecasts" (Meltzer 2009, p.45, p. 498). When Riefler retired in 1959 and was succeeded by Young, "there [was] an unleashing of staff brainpower," Business Week journalists remarked. More staffers entered policy debate, the article continues, and Meltzer adds that "the methods taught in graduate schools such as econometric forecasts and economic models" were introduced (2009, p. 498).

An unsuccessful memorandum Noyes and Young drafted in 1960 to stir the Board toward funding the SSRC model highlights a potential reason why the institutionalist directors supported macroeconometrics. ${ }^{41}$ According to the minutes, the memorandum "pointed out that the Board's flow of funds accounts might well provide the statistical framework for much of the analysis." Young and Noyes may thus have seen in the project an opportunity to use the hitherto under-used flow of funds accounts they had been building since Copeland's 1947-52 project. The Board had done some work to use them for projections in the early 1950s and Riefler stated in 1953 that Brill "ha[d] been most ingenious and original in making the new material [the flow-of-funds accounts] 'talk." "42 Indeed, in their memo, the two officials

40 “The Fed remodels itself," Business Week, May 16, 1964.

${ }^{41}$ The Board's discussion on the Committee's proposal for funding is summarized in the September 23, 1960 minutes of the meetings of the Board of Governors.

${ }^{42}$ Riefler to Committee on Selection of the Rockefeller Public Service Award, August 31, 1953, WWSPIA. 
advertised the SSRC project as a projection tool: "the project would undertake to explore the potentialities of econometric methods of projecting the economy's future performance and assess the utility of these methods as a supplement to other approaches to economic projection," they wrote. ${ }^{43}$ The report therefore minimized the policy analysis goal of the project. Also, the reasons why Noyes and Young used the "projection" rather than hitherto anathema "forecast" language are unclear. It could have reflected a misunderstanding of the orientation of the SSRC model, or a deliberate strategy from DRS officials to stir the Board toward greater use of up-todate econometric techniques and the systematic use of forecasts for FOMC decisions. By the mid-1960s, external and internal pressures had warmed the FOMC up to these new ideas. The combination of mechanical forecasts and judgments, of science and art would however prove a difficult endeavor.

\section{SCIENCE IN SUPPORT OF THE ART: A DIFFICULT CROSS- FERTILIZATION}

The development of a macroeconometric model

After the model of the SSRC's Committee on Economic Stability was handed over to the Brookings Institution for further development in 1963, economists at the DRS sensed that the enhanced understanding of the transmission mechanisms whereby monetary policy decisions influence output and the systematic forecasts necessary to

\footnotetext{
${ }^{43}$ Board minutes, September 23, 1960.
} 
improve the Board's decision-making process required yet another macroeconometric model. During a 1965 conference on investment organized at the Board, Brill reported that:

the Federal Reserve is currently pursuing a comprehensive research project on linkages between monetary policy and the general economy. Working groups in the Federal Reserve have been formed to study: (1) the entire linkage process from Federal Reserve actions to spending decisions, (2) the linkages among money market variables, such as between open market operations and member banks reserves, and (3) the linkages between money market variables and more basic financial variables, such as between bank reserves and the money supply. ${ }^{44}$

The DRS economists, however, were not alone in believing that another model should be developed. According to University of Pennsylvania macroeconomist Albert Ando, the newly-founded SSRC's Subcommittee on Monetary Research had come to the same conclusion. ${ }^{45}$ Ando was then involved, together with his former Carnegie colleague Modigliani, in a heated academic exchange with Friedman and his

${ }^{44}$ Conference minutes, April 2-3, 1965, SSRC1. This work was "largely under the immediate direction of Frank de Leeuw," Brill reported to incoming governor Brimmer. March 10, 1966, p. 2, AFBP.

${ }^{45}$ Ando, "Introduction," undated but probably 1968, FMP. The Subcommittee was part of the Committee on Economic Stability. Initial meetings of what came to be the Subcommittee were held at and funded by the Board of Governors. 
student David Meiselman over the respective influence of fiscal and monetary policy over consumption and the business cycle. Monetarist ideas were gaining traction, which called for a detailed empirical reexamination of the influence of monetary variables on the real sector, and Ando and Modigliani were eager to direct such project from MIT and Penn. ${ }^{46}$

Settling an academic dispute through empirical work was arguably a different motive from improving Fed decision-making. But the minutes of the 1965 conference on investment attest that both Brill and Modigliani were aware of the complementarity of the two groups. "Because the SSRC working group [...] is already investigating the linkages between basic financial variables and final spending decisions, the Federal Reserve is presently concentrating most of its resources on the earlier linkages in the process," Brill explained. "Modigliani proposed the closest cooperation between the two groups," the minutes then read. ${ }^{47}$ An official merger of

\footnotetext{
${ }^{46}$ In a 1969 talk, DRS economist (and future Governor) Edward Gramlich likewise insisted that "a hot dispute currently rages as to the importance of money in influencing econ activity ... The FRB-MIT econometric model ... originated in this controversy.... [Modigliani and Ando] were spurred on in an attempt to resolve their inconclusive interchange with Friedman-Meiselman in the 1965 American Economic Review." "Complicated and simple approaches to Estimating the role of money on economic activity," 06/05/1969, Edward Gramlich papers.

${ }^{47}$ Conference minutes, April 2-3, 1965, box 147, folder 812, SSRC1. Modigliani's ex post assertion that "the Fed wanted the model to be developed outside, the academic community to be aware of this decision, and the result not to reflect its ideas on how
} 
the two projects was enacted in 1966, and the Board funded the joint model until December of $1970 .{ }^{48}$ A Special Studies Section had been created at the DRS to house their econometric work, and De Leeuw, its leader, was chosen to co-direct the new model project with Ando and Modigliani. He was seconded by Edward Gramlich, who joined the Board in 1965 after completing a $\mathrm{PhD}$ at Yale under Tobin on the effects of fiscal policy on aggregate demand (Gramlich 1997). ${ }^{49}$

The resulting "FRB-MIT-Penn" or "FMP" model was different from the cohort of other macroeconometric models developed in the 1960s in that it "contains many more policy variables that can be used directly to represent the policy actions of to operate" (2001, p. 101) therefore does not reflect the process through which the model actually developed.

${ }^{48} \mathrm{We}$ unfortunately do not have records of the discussions regarding the funding of the project by the Board, which would surely help us understand Martin and others' views on the project. We do know that, though clearly very expensive, Brill considered it to be "one of the most exciting adventures in which [the DRS] ha[d] embarked.” Brill to Brimmer, March 10, 1966, p. 6, ADBP. In 1971 a copy of the current version of the model was handed over to Wharton Economic Forecasting Associates Inc. (WEFA) for maintenance and distribution. Ando to Hickman, July 19, 1971, FMP. The Board continued to develop their own version of model throughout the 70s and 80s. See Brayton et al. (1997) for a brief discussion of the macroeconometric models developed at the Board.

49 See Backhouse and Cherrier (2019) for a detailed account of each group's perspective and on the organization of the (not so) joint work in developing the model. 
the monetary and fiscal authorities of the federal government." ${ }^{50}$ It exhibited the usual blocks of equations (consumption, investment, financial sector, housing), but with twists that allowed for more numerous and refined transmission mechanisms than the cost-of-capital effects that previous macroeconometric models relied on. The consumption equations allowed for detailed wealth effects, and credit rationing in the mortgage market was also taken into account. The influence of interest rates on state and local public expenditures also received specific attention. ${ }^{52}$

The goals and modeling practices of the two groups were nonetheless different enough that two models were initially developed. Even after they were merged in 1968, several versions coexisted (Backhouse and Cherrier 2019). Brill had indeed warned Modigliani that he wanted to "preserve the identity of our [the DRS] contribution to the project," suggesting that it would help them to increase the staff devoted to model-building and to remain autonomous in operating their version. ${ }^{53} \mathrm{He}$ also needed a distinct identity so that the Board would not be publicly associated with strange model outputs: "Obviously it would have to be made clear that these results did not necessarily reflect the views of the Board or the staff....I can foresee the possibility of distinct embarrassment to the System from widespread publicity given

\footnotetext{
${ }^{50}$ Ando, "Introduction," FMP.

${ }^{52}$ De Leuuw and Gramlich (1969) offer a succinct description of the model. See Acosta and Rubin (2019) for a discussion of the role of banks in the FMP and other contemporary large-scale macroeconometric models.

${ }^{53}$ Brill to Brimmer: Number of people; he also says it has been a limited operation, with most of the people involved also having administrative responsibilities. And they would like to keep it that way.
} 
to strange results of early simulation runs of an untested model," he wrote to Modigliani. ${ }^{54}$

The differences in purposes and approaches showed up on many occasions. At the beginning of 1969, Ando explained that the "academic side" wanted to postpone "the work involved in putting together the model and concentrated on improvements of each equation." On the contrary, the DRS team "must have a functioning system as soon as possible." They had already started operating their model in November 1967, almost a year before the MIT-Penn economists. ${ }^{55}$ Constraints and purposes may have been different but other interventions speak to a shared "macroeconomics" identity and how blurred the boundaries between academic and policy-circles were. All participants understood the FOMC's reservations with "mechanical” forecasts. As he presented the model to the Board in 1968, Ando emphasized the complementarity between macroeconometrics and "experts' judgments":

it is not necessary to use the model mechanically for the purpose of forecasting...it is easy to insert into the model judgmental forecasts made by experts for housing expenditures, and rerun the model to obtain the conditional forecast of all other variables... Thus, it is hoped that the model will perform many of the routine chores

\footnotetext{
${ }^{54}$ Brill to Modigliani, July 6, 1966, SSRC2. The note that appeared on the January, 1971 issue of the Federal Reserve Bulletin reporting the agreement reached with WEFA also made it clear that the model currently at use at the Board was different from the one being distributed (p. 76).

${ }^{55}$ Ando to Brill, 01/10/1969, FMP
} 
currently performed by the experts, and free them to concentrate on more crucial and difficult aspects of econ analysis. ${ }^{56}$

The next year, Gramlich repeated the same argument to the Committee on Banking and Credit Policy: "Model forecasts can increase the mechanical advantage of judgmental forecasters ... models can take care of the major economic relationships and allow judgmental forecasters to worry exclusively about specific developments," he explained. ${ }^{57}$

Conversely, Fed economists were painfully aware that, beyond the intrinsic challenges of communicating the model's simulation to a skeptical FOMC, they had to cope with the fallouts of the debates between Keynesians and Monetarists within the Fed. The 1960s saw the emancipation of the Reserve Banks' research departments, hitherto devoted to data collection. In the Federal Reserve Bank of St. Louis, Jerry Lee Jordan took over the practice of writing simple, single-equation

\footnotetext{
${ }^{56}$ Ando, "Introduction," ibid.

57 Gramlich, "Recent experience with the FRB-MIT model," Presented to the Committee on Banking and Credit Policy, New York, 11/06/1969, Edward Gramlich papers. Years earlier De Leeuw had requested to be transferred to the National Income Section of the DRS, which was responsible for the judgmental forecasting work. De Leeuw believed, and Brill agreed with him, that "a closer interchange between the formal model-builders and those using essentially judgmental techniques will produce a much more reasonable and useful model, enabling us to incorporate more systematically the wealth of institutional knowledge and understanding of the numbers our staff possesses." Brill to Brimmer, March 3, 1966, p. 3, AFBP.
} 
models. Together with Leonall Andersen they wrote a single-equation model which correlated the levels and differences in money supply and expenditures with income to assess the relative importance and speed of fiscal and monetary policy. It threw macroeconomists into years of theoretical, empirical, methodological, and policy intertwined debates. Modigliani, Ando, Brunner, Meltzer, and Gramlich participated in a controversy played out in academic journals as well as Board bulletins and Reserve Banks' reviews. ${ }^{58}$ In Minnesota, staff economists Thomas Muench, Arthur Rolnick, William Weiler, and specific advisor and Minnesota professor Neil Wallace were working on a devastating assessment of the prediction generated by the FRB and Michigan Quarterly models. ${ }^{59}$

Bringing forecasts to the FOMC: the making of the Green and Blue Books

Around the time the Board decided to build its own macroeconomic model, the internal pressure to rationalize the FOMC decision-making process resulted in concrete changes in procedures. First, Martin agreed to establish a second committee to reform the directive in the late 1960s. It was led by FOMC Secretary, and future Board Governor, Robert Holland, Governor Maisel, and DRS's James Pierce. ${ }^{60}$

\footnotetext{
${ }^{58}$ See Rancan (2019) for an exhaustive account of the battles around the FMP and St Louis model, in particular the Andersen-Jordan equation.

${ }^{59}$ The paper was published in 1974 , but it was under way in the late 1960 s already (interview of Rolnick by Cherrier, June 2018, University of Minnesota)

${ }^{60}$ Pierce remembers that they also worked with MIT engineers on the application of control theory to their problem (Pierce 1996a, p. 34). Mention here Pedro's paper on the cuadratic loss function?
} 
Second, "a formal forecasting system" was inaugurated; a development Maisel takes credit for: "The first memorandum I wrote after being appointed to the Board suggested the vital need for such a system. Projections of the GNP, credit, or the money supply were totally lacking at the time" (1972, p. 176). He asked the DRS to prepare data outlining recent past and "projected" evolutions of nine series of variables, from monetary instruments, monetary and fiscal variables to real and nominal output, prices unemployment, and balance of payment variables. ${ }^{61}$ Each table was accompanied with a paragraph detailing the probable sources for recent evolutions (for instance negotiations in the steel industry explained some price changes), and the whole was assembled in a document titled "Current Economic and Financial Conditions" sporting a green cover. This so-called "Greenbook" was first distributed in advance of the June 10, 1964 FOMC meeting. An updated version was then circulated before every meeting, and the forecasts were more substantially updated every three months or so.

By the end of the year, Brill, now head of the DRS, seems to have asked staff economist Stephen Axilrod to transform a chart of money indicators into an outline of possible scenarios for monetary policy operation the FOMC might choose from (Axilrod 2001, pp. 45-46). These would be based on carefully chosen monetary

${ }^{61}$ Given the lag with which national statistics were made available at the time, what was being "forecasted" was in fact the present, and the short-term future, one or two quarters ahead (see Pierce 1995). Axilrod (2001, pp. 41-42) explained that the term "projection" was purposely chosen over "forecast" because "the former term seemed more professional and less likely to raise questions about whether they did or did not represent satisfactory outcomes." 
parameters (interest rates, but also reserve measures) with the purpose of "quantifying," and thus making more specific, the instructions in the directive the FOMC transmitted to the Tradig Desk manager at the New York Fed after each meeting. This "Bluebook," originally implemented for the November 2, 1965 meeting, quickly grew in size. At the end of the discussion, "possible directive language" was presented as a set of 3 indicative policy alternatives (A, B and C). ${ }^{62} \mathrm{~A}$ “Redbook” summarizing economic conditions by district was added in 1970 .

These forecasts or "projections" were initially purely judgmental. DRS econometrician James Pierce later recounted that they were provided by what econometricians called "judgmental economists" or "business economists... really expert about what was going on in their sector [...] You just stare at the wall and figure out what's going to happen — that's how the [Greenbook] forecasts were made" (1995, pp. 31-32). A major issue was that this practice paradoxically left no role for monetary and financial variables to play. As they became available around the end of 1967, forecasts resulting from the FRB model's simulation did not replace these judgmental forecasts. DRS officials knew Martin and other Board members' resistance to "mechanical forecasts," and they personally seemed to adhere to the idea that monetary policy operations required a blending of science and art. Brill, Axilrod, Pierce, and then Charles Partee and Lyle Gramley thus tried to blend judgment and econometric models. Maisel insisted that "policy is not based on a literal acceptance of any specific model [but] develops from...debate which allow[s] for the inclusion of

62 See for instance the bluebook for the December 15, 1970 meeting: https://www.federalreserve.gov/monetarypolicy/files/FOMC19701215bluebook19701

\section{1.pdf}


judgments about the economy and the model and value judgments as to goals" (1973, p. 180). To Pierce, the addition of model forecasts "forced a discipline" in that the monetary and real sector got better integrated.

The DRS's cautious approach to the introduction of new practices initially appeared quite successful, though it created tensions between the econometric "technicians" and other breeds of analysts. ${ }^{63}$ It was, however, thwarted by their failure to predict the economic consequences of the 1968 tax surcharge implemented by Johnson to curb inflation. The decrease in spending predicted by the staff, which would support a pause in the tightening of monetary policy, failed to materialize and put the Fed in the uncomfortable position of implementing a restrictive policy and potentially suffocating the economy or waiting and potentially letting inflation mount (Bremner 2004, pp. 252-254). Virtually all accounts by former Fed officials consistently identify this forecasting debacle as a turning point, and it likely contributed to Brill's resignation in $1969 .{ }^{64}$ Although Martin also leaned towards ease then, the 1968 failure contributed to his distrust of the staff's forecasts. As inflation intensified in 1969, Martin, now pushing for restraint, criticized the staff's confidence in their forecasts despite their previous failures. He and some Board members felt the staff and its projections had misled them, and Martin later reportedly reaffirmed that

${ }^{63}$ Pierce profoundly disliked being called a technician, which he felt was done to dismiss any of his expertise besides the purely technical aspects of econometric modeling (Pierce 1995, p. 43).

${ }^{64}$ Frank Morris (1994a, pp. 8-10), James Parthemos (1994, pp. 11-13), Pierce (1995, pp. 1-2), Axilrod (2011, p. 45). Brill went to work in the private sector, at \#\#\#\#\#. Frank de Leeuw also left the Board in 1969 and went to the Urban Institute. 
he would rather "dispense with the kind of analysis presented in the Bluebook" (Bremner 20014, p. 271) and added that "there is a disease called statisticalitis that could kill us" (p273).

The internal purchase of econometric methods did not improve with Burns' nomination as chairman in 1970 . Despite being the chairman to hold a $\mathrm{PhD}$, and a widely renowned academic at that, "he was an institutionalist ... more than anything else," Holland highlights (reff \#\#\#). "He consumed economic data in big volumes," he added, in line with Richmond Fed's president Robert Black's recollections: "he believed in distilling — because of his work at the NBER — huge amounts of empirical information and drawing conclusions from that" (reff \#\#\#). Maisel (1973, p. 122) even remembered that he supplemented Board's staff work with his own sources of information. His self-confidence was also, by all accounts, psychological. Unlike Martin, often pictured as a "consensus-seeker," Burns was hailed as an "old autocrat" (Black 1994, p. 6). \#\# Black and James Parthemos, former president and vice president of the Richmond Fed, both considered that the chairman "ran those [FOMC] meetings like a graduate seminar" (Black 1994, p. 8; Parthemos 1994, p. 15). Burns also found the DRS much too "Keynesian" for his taste (Parthemos 1994, p. 16). Finally, he understood monetary policy making as a scientific, artistic, but also highly political endeavor.

\section{Burns' style led to further marginalization of macroeconometrics in the} decision-making process. Pierce, who became a major antagonist to Burns in this period, explained that the prioritization of short-term judgmental forecasts allowed the chairman to rely on conservative projections that vindicated his desire to tighten 
monetary policy in response to growing inflation. The econometrician acknowledged that these judgmental forecasts were more accurate that short-term econometric forecasts (see also Maisel 1973, pp. 181-2), but he believed econometricians were better able to predict if the economy might slip into recession with time (Pierce 1996a, p. 21). Burns did not, however, dismiss the Bluebook, as Martin had been tempted to do. He instead bent it to fit his own policy agenda. Pierce remembers that scenario B, the middle position, was toughly negotiated with Burns:

The one they were supposed to vote on was B. And B was the thing that Burns wanted them to do, so he'd get together with Axilrod and he'd tell Axilrod what he wanted. And then we were supposed to come up with stuff that matched that. ... It was all sort of a sham. The decisions were made ahead of time" (Pierce 1995, p. 22)

Former DRS advisor Peter Keir's recollections are consistent with Pierce's. He explained that then DRS director and Board advisor Charles Partee "would be very aggressive for, say, ... typically for lowering the funds rate, which I think was alternative C in the Bluebook" (Keir 1994, p. 17) and then Burns would go for B, which was more moderate. It was all orchestrated. ${ }^{65}$

\section{CONCLUSION}

\footnotetext{
${ }^{65}$ Holland explained that Burns relied on Partee and Lyle Gramley, whom he trusted as "analysts," to "filter the works of the rest of the econometrics modeling staff" (Holland 1994, p. 45).
} 
The claim that the history of central banking is characterized by a trend toward "scientization" is widely accepted. It is one seen in quantitative accounts of the transformation of the background of Fed recruits across time, and their growing contribution to academic journals. Yet, the story of how economic analysis was gradually embedded in the Fed's decision-making process outlined in this paper belies the idea of a linear irresistible takeover by newly minted $\mathrm{PhD}$ economists. To some extent, mounting criticisms of monetary policy operations since the 1950s spurred a gradual replacement of lawyers, bankers and businessmen with academically trained economists at the Board and the Regional banks. Symptomatic of this shift was the nomination of Burns, the first PhD-economist as chairman in 1970.

This transformation should not, however, be interpreted as a replacement of old-style data and intuition-based evaluation of the economic situation by sophisticated large-scale macroeconometric models. At the DRS, which had always been directed by professional economists, several styles of research cohabited, were blended, or clashed. "Judgmental" and "mechanical" economics were combined in documents carefully crafted to appeal to FOMC members with diverse backgrounds. Furthermore, the shift toward new forms of analysis was engineered by economists who either had no $\mathrm{PhD}$, or completed one during their career at the DRS. It was not their training that was key to their endorsement of macroeconometrics, but their participation into collective endeavors (for Brill) or the external pressures they faced (for Martin and FOMC members). Finally, the use of the books and underlying forecasts was resisted, by non-economists as well as by $\mathrm{PhD}$ economists who favored institutionalist styles of analysis. By the mid-1970s, styles of research like macroecoeconometrics were already challenged in the academia, but they were still 
influential in the Fed's decision-making process. The road toward scientization was a long and bumpy one. 


\section{REFERENCES}

\section{Archival:}

AFBP: Andrew F. Brimmer Papers, box 125, folder 2. Baker Library, Harvard University.

EGP: Edward Gramlich Papers, Bentley Historical library, University of Michigan.

FMP: Franco Modigliani Papers, Rubinstein Library, Duke University.

JFKA: John Fitzgerald Kennedy Online Archives.

WWSPIA: Woodrow Wilson School of Public and International Affairs Records, box 35, folder 17. Seely G. Mudd Manuscript Library, Princeton University.

SSRC1: Record Group 1, Accession 1, Series 1, Subseries 19. Rockefeller Archive Center, Records of the SSRC.

SSRC2: Record Group 2, Accession 2, Series 1, Subseries 23. Rockefeller Archive Center, Records of the SSRC

\section{Published:}

“The Fed Remodels Itself.” 1964. Business Week, May, 65-76.

Ackley, G. 1974, “Interview by Joe Franz”, 7 March, Oral History Transcript, Lyndon B. Johnson Library Oral Histories.

Acosta, J. Pinzon-Fuchs, E. 2017. "Macroeconometric Modeling and the SSRC's Committee on Economic Stability, 1959-1963," CHOPE working paper, https://papers.ssrn.com/sol3/Papers.cfm?abstract_id=3175933

Acosta, J. Rubin, G. 2019. "Bank agency in early large-scale macroeconometric 
models of the 1960s." History of Political Economy 51 (3): 471- 491.

Axilrod, Stephen H. 2011. Inside the Fed. MIT Press.

Backhouse, R. Cherrier, B. 2019. “The ordinary business of macroeconometric modeling: working on the MIT-Fed-Penn model (1964-1974)." History of Political Economy 51 (3): 425-447.

Baker, Dean, Sarah Rawlins, and David Stein. 2017. "The full employment mandate of the Federal Reserve: its origins and importance." CEPR report, available at http://cepr.net/publications/reports/full-employment-mandate-of-the-fed

Ban, Cornel. 2018. "The Professional Politics of the Austerity Debate: Comparing the European Central Bank and the International Monetary Fund." CIYPERC working paper.

Black, Robert. 1994. “Interview by Robert Hetzel, June 6.” Available at https://fraser.stlouisfed.org/archival/4927

Bodkin, Ronald G., Lawrence Klein, and Kanta Marwah. 1991. A History of Macroeconometric model-building. Aldershot, Hants, England; Brookfield, Vt., USA: Edgar Elgar

Bordo, Michael, and Klodiana Istrefi. 2018. "Perceived FOMC: The making of hawks, doves, and swingers.” Hoover Institution, Economics Working Paper 18108.

Bordo, Michael. 2008. “Monetary Policy, History of.” In Steven Durlauf and Lawrence Blume (eds). The New Palgrave Dictionary of Economics. Palgrave Macmillan. 
Brayton, Flint, Andrew Levin, Ralph Lyon, and John C. Williams. 1997. “The Evolution of Macro Models at the Federal Reserve Board." Carnegie-Rochester Conference Series on Public Policy 47 (December): 43-81.

Bremner, Robert P. 2004. Chairman of the Fed: William McChesney Martin Jr., and the Creation of the Modern American Financial System. Yale University Press.

Brunner, Karl, and Allan Meltzer. 1964a. Some General Features of the Federal Reserve's Approach to Policy. Subcommittee on Domestic Finance, Committee on Banking and Currency of the House of Representatives.

Brunner, Karl, and Allan Meltzer. 1964b. The Federal Reserve's Attachment to the Free Reserve Concept. Subcommittee on Domestic Finance, Committee on Banking and Currency of the House of Representatives.

Brunner, Karl, and Allan Meltzer. 1964c. An Alternative Approach to the Monetary Mechanism. Subcommittee on Domestic Finance, Committee on Banking and Currency of the House of Representatives.

Burns, Arthur F. 1946. Measuring Business Cycles. New York: National Bureau of Economic Research.

Cherrier, B. 2018. "How to Write a Memo to Convince A President: Walter Heller and the Kennedy tax Cut.” working paper, September 2018.

Claveau, F. Dion, J. 2018. “Quantifying Central Banks' Scientization: Why and How to Do a Quantified organizational History of Economics." Journal of Economic Methodology 25 (4): 339-366.

Congress of the United States of America. 1964. The Federal Reserve after fifty years: Hearings before the Subcommittee on Domestic Finance of the Committee on 
Banking and Currency, House of Representatives. Washington: US Government Printing Office.

Conti-Brown, Peter. 2017. The power and independence of the Federal Reserve. Princeton University Press.

Daane, Dewey. 2006. "Interview for the Federal Reserve Oral History Project, June 1.” Available at https://www.federalreserve.gov/aboutthefed/files/j-dewey-daaneinterview-20060601.pdf

DeLeeuw, Frank. 1964. "Financial Factors in Business Cycles : a Simulation Study." American Economic Review 54 (3): 309-323.

De Leeuw, Frank. 1965a. “A Model of Financial Behavior.” In James Duesenberry, Gary Fromm, Lawrence Klein, and Edwin Kuh, eds., The Brookings Quarterly Econometric Model of the United States. Chicago, Ill: Rand-McNally

DeLeeuw, 1965b, “A Model of Financial Behavior," dissertation, Harvard University. DeLeeuw, F. Gramlich, E. 1969. "The Channels of Monetary Policy.” Federal Reserve Bulletin June: 472-91.

De Vroey, Michel. 2016. A history of macroeconomics from Keynes to Lucas and beyond. Cambridge University Press.

Enzler, Jared. 2013. "Interview for the Federal Reserve Oral History Project, June 26." Available at https://www.federalreserve.gov/aboutthefed/files/jared-enzlerinterview-20130626.pdf

Ettin, Edward. 2006. "Interview for the Federal Reserve Oral History Project, March 10.” Available at https://www.federalreserve.gov/aboutthefed/files/edward-c-ettininterview-20060310.pdf 
Feiertag, Olivier and Michel Margariaz, 2016. Les banques centrales et l'État-nation. Les presses de Sciences Po.

Fox, Justin. 2014. "How economics PhDs took over the Federal Reserve." Harvard Business Review Online (Febraury 3), accessed August 12, 2019, https://hbr.org/2014/02/how-economics-phds-took-over-the-federal-reserve.

Gramley, Lyle. 2007. "Interview for the Federal Reserve Oral History Project, May 14." Available at https://www.federalreserve.gov/aboutthefed/files/lyle-e-gramleyinterview-20070514.pdf

Gramlich, E. 1997. Reflections of a policy economist, American Economist 41 (1): $22-30$

Gramlich, Edward M. 2004. The Board's Modeling Work in the 1960s. Delivered at the Federal Reserve Board Models and Monetary Policy Conference, Washington, D.C. March 26. Accessed August 12, 2019, https://www.federalreserve.gov/boarddocs/speeches/2004/20040326/default.htm.

Gramlich, Edward. 2007. "Interview for the Federal Reserve Oral History Project, August 8." Available at https://www.federalreserve.gov/aboutthefed/files/edward-mgramlich-interview-20070808.pdf

Hetzel, Robert L. 2008. The Monetary Policy of the Federal Reserve: A History. Cambridge University Press.

Hetzel, R. Leach, 2012. “The Treasury-Fed Accord: A New Narrative Account." FRB Richmond Economic Quarterly 87 (1): 33-56.

Heller, W. W. 1967. New Dimensions of Political Economy. New York: Norton. Holland, Robert. 1994. "Interview by Robert Hetzel, July 13.” Available at 
https://fraser.stlouisfed.org/archival/4927

Hoover, Kevin. 1990. The New Classical Macroeconomics: A Skeptical Inquiry. Blackwell.

Hoover, Kevin. 2018. “Karl Brunner's Philosophy of Science: Macroeconomics through the Lens of Logical Empiricism." Center for the History of Political Economy Working Paper 2018-15.

Keir, Peter. 2001. “Interview by Robert Hetzel, July 17.” Available at https://fraser.stlouisfed.org/archival/4927

Kichline, James. 2007. "Interview for the Federal Reserve Oral History Project, September 21." Available at https://www.federalreserve.gov/aboutthefed/files/james1-kichline-interview-20070921.pdf

Knipe, James. 1962.“A summary of public criticism of the Federal Reserve System, 1959-1961.” Available at https://fraser.stlouisfed.org/files/docs/historical/martin/21_04_19620209.pdf.

Koopmans, Tjalling C. 1947. "Measurement Without Theory." The Review of Economics and Statistics 29 (3): 161-72.

Lebaron, Frédéric. 2012. “A Universal Paradigm of Central Banker?” Social Glance. Journal of Social Sciences and Humanities 1 (1): 40-59.

Maisel, Sherman. 1973. Managing the Dollar. Norton.

Maisel, Sherman. 2009. “Interview for the Federal Reserve Oral History Project, July 8." Available at https://www.federalreserve.gov/aboutthefed/files/sherman-j-maiselinterview-20090708.pdf 
Mallaby, Sebastian. 2016. The Man Who Knew: The Life \& Times of Alan Greenspan. Bloomsbury Publishing.

Mankiw, N.G., 2006. The Macroeconomist as Scientist and Engineer. Journal of Economic Perspectives 20, 29-46.

Marcussen, Martin. 2009. "Scientization of Central Banking." In Kenneth Dyson and Martin Marcussen, eds., Central Banks in the Age of the Euro: Europeanization, Convergence, and Power. Oxford University Press, pp. 373-390.

McGregor, Roy, and Warren Young. 2013. "Federal Reserve Bank presidents as public intellectuals," History of Political Economy 45 (suppl.): 166-190.

Mehrling, Perry. 2010. The new Lombard street: how the Fed became the dealer of last resort. Princeton University Press.

Meltzer, Allan H. 2003. A History of the Federal Reserve, Volume 1: 1913-1951. University of Chicago Press.

Meltzer, Allan H. 2009. A History of the Federal Reserve, Volume 2. University of Chicago Press.

Mirowski, P. 1989. “The measurement without theory controversy : defeating rival research programs by accusing them of naive empiricism" Economies et Sociétés 11. Mongin, P. 1997. "The Marginalist Controversy" in J. Davis, W. Hands and U. Maki eds., The Handbook of Economic Methodology. London: Edward Elgar, pp. 558-562. Monnet, Eric. 2014. “Monetary Policy without Interest Rates: Evidence from France's Golden Age (1948 to 1973) Using a Narrative Approach,” American Economic Journal: Macroeconomics, American Economic Association 6(4): 137-169.

Morgan, M. Rutherford, (eds) 1998. From Interwar Pluralism to Postwar Neoclassicism, special Issue of History of Political Economy 30 (suppl.): 1-26. 
Morris, Frank. 1994a. "Interview by Robert Hetzel, March 10.” Available at https://fraser.stlouisfed.org/archival/4927

Parthemos, James. 1994. "Interview by Robert Hetzel, June 10.” Available at https://fraser.stlouisfed.org/archival/4927

Pierce, James. 1995. "Interview by Robert Hetzel, April 27." Available at https://fraser.stlouisfed.org/archival/4927

Pierce, James. 1996a. “Interview by Robert Hetzel, April 10.” Available at https://fraser.stlouisfed.org/archival/4927

Pierce, James. 1996b. “Interview by Robert Hetzel, July 1.” Available at https://fraser.stlouisfed.org/archival/4927

Rancan, A. 2019. "Empirical Macroeconomics in a Policy Context: The Fed-MITPenn Model versus the St. Louis Model, 1965-75." History of Political Economy 51 (3): $449-470$.

Ritter, L.S. 1962. "Official Central Banking Theory in the United States, 1939-61: Four Editions of the Federal Reserve System: Purposes and Functions.” Journal of Political Economy 70(1): 14-29.

Ritter, Lawrence S., ed. 1980. Selected Papers of Allan Sproul. Federal Reserve Bank of New York.

Rutherford,M. 2011. The Institutionalist Movement in American Economics, 19181947: Science and Social Control. Cambridge and New York: Cambridge University Press.

Schnidman, Evan, and William MacMillan. 2016. How the Fed Moves Markets: Central Bank Analysis for the Modern Era. Palgrave Macmillan. 
Snowdon, Brian, and Howard Vane. 2005. Modern macroeconomics: its origins, development, and current state. Edward Elgar Publishing.

Stockwell, Eleanor, ed. 1989. Working at the Board: 1930s-1970s. Washington:

Board of Governors of the Federal Reserve System.

Tobin, J. 1961. "The Future of the Fed.” Challenge 4(9): 24-28.

Woodford, M., 2009. Convergence in Macroeconomics: Elements of the New Synthesis. American Economic Journal: Macroeconomics 1, 267-279.

Yohe, William P. 1990. "The Intellectual Milieu at the Federal Reserve Board in the 1920s." History of Political Economy 22 (3): 465-488.

Young, Nancy Beck. 2000. Wright Patman: Populism, Liberalism, and the American Dream. Southern Methodist University Press. 


\section{Annexes}

The information presented in the following tables was obtained from the Federal Reserve's History website (www.federalreservehistory.org), the Federal Reserve Bulletin, and the lists of dissertations published by the American Economic Association. When possible, the catalogues of university libraries were used to corroborate, or in some cases correct, the information present in the other sources.

\section{Table 1: Board of Governors, 1951-1975 (PhD economists identified with *)}

\begin{tabular}{lllll} 
Apr-51 & Apr-61 & May-65 & Feb-70 & Mar-75 \\
\hline Martin [c] & Martin [c] & Martin [c] & Burns* [c] & Burns* [c] \\
Eccles & Balderston* $[\mathrm{vc}]$ & Balderston* [vc] & Robertson [vc] & Mitchell [vc] \\
Szymczak & Szymczak & Robertson & Mitchell & Coldwell* \\
Evans & Mills & Shepardson & Daane* & Holland* \\
Vardaman & Robertson & Mitchell & Maisel* & Sheenan \\
Norton & Shepardson & Daane* & Brimmer* & Bucher \\
Powell & King & Maisel* & Sherrill & Wallich*
\end{tabular}




\section{Table 2: Appointments of Board members after first PhD economist in the}

\section{period.}

\begin{tabular}{|c|c|c|c|c|c|}
\hline Name & Appointed & $\begin{array}{l}\text { Years } \\
\text { after } \\
\text { PhD }\end{array}$ & Appointed by & $\begin{array}{l}\text { Terminal } \\
\text { degree }\end{array}$ & Institution \\
\hline Balderston & 1954 & $26(1928)$ & Eisenhower [R] & $\mathrm{PhD}$ & Pennsylvania \\
\hline Shepardson & 1955 & & Eisenhower [R] & MSc (Ag., 1924) & Iowa State \\
\hline King & 1959 & & Eisenhower $[\mathrm{R}]$ & BS (1941) & Louisiana State \\
\hline Mitchell & 1961 & & Kennedy [D] & BA (1925) & Wisconsin \\
\hline Daane & 1963 & 14 (1949) & Kennedy [D] & $\mathrm{PhD}$ & Harvard \\
\hline Maisel & 1965 & $16(1949)$ & Johnson [D] & $\mathrm{PhD}$ & Harvard \\
\hline Brimmer & 1966 & $9(1957)$ & Johnson [D] & $\mathrm{PhD}$ & Harvard \\
\hline Sherrill & 1967 & & Johnson [D] & MBA (1952) & Harvard \\
\hline Burns & 1970 & $36(1934)$ & Nixon [R] & $\mathrm{PhD}$ & Columbia \\
\hline Sheenan & 1972 & & Nixon [R] & MBA (1960) & Harvard \\
\hline Bucher & 1972 & & Nixon [R] & JD (1956) & Stanford \\
\hline Holland & 1973 & $14(1959)$ & Nixon $[R]$ & $\mathrm{PhD}$ & Pennsylvania \\
\hline Wallich & 1974 & 30 (1944) & Nixon $[R]$ & $\mathrm{PhD}$ & Harvard \\
\hline Coldwell & 1974 & $22(1952)$ & Ford $[R]$ & $\mathrm{PhD}$ & Wisconsin \\
\hline
\end{tabular}


Table 3: Presidents of Federal Reserve Banks, 1951-1975 (PhD economists

\section{identified with *)}

$\begin{array}{llllll}\text { Reserve Bank } & \text { Apr-51 } & \text { Apr-61 } & \text { May-65 } & \text { Feb-70 } & \text { Mar-75 } \\ \text { Atlanta } & \text { Bryan } & \text { Bryan } & \text { Bryan } & \text { Kimbrel } & \text { Kimbrel } \\ \text { Boston } & \text { Erickson } & \text { Ellis* } & \text { Ellis* } & \text { Morris* } & \text { Morris* } \\ \text { Chicago } & \text { Young } & \text { Allen } & \text { Scanlon } & \text { Scanlon } & \text { Mayo } \\ \text { Cleveland } & \text { Gidney } & \text { Fulton } & \text { Hickman* } & \text { Hickman* } & \text { Winn* } \\ \text { Dallas } & \text { Gilbert } & \text { Irons* } & \text { Irons* } & \text { Coldwell* } & \text { Baughman } \\ \text { Kansas } & \text { Leedy } & \text { Clay } & \text { Clay } & \text { Clay } & \text { Clay } \\ \text { Minneapolis } & \text { Peyton } & \text { Deming* } & \text { Galusha } & \text { Galusha } & \text { MacLaury* } \\ \text { New York } & \text { Sproul } & \text { Hayes } & \text { Hayes } & \text { Hayes } & \text { Hayes } \\ \text { Philadelphia } & \text { Williams* } & \text { Bopp* } & \text { Bopp* } & \text { Bopp* } & \text { Eastburn* } \\ \text { Richmond } & \text { Leach } & \text { Wayne } & \text { Wayne } & \text { Heflin } & \text { Black* } \\ \text { San Francisco } & \text { Earhart } & \text { Swan } & \text { Swan } & \text { Swan } & \text { Balles* } \\ \text { St. Louis } & \text { Johns } & \text { Johns } & \text { Shuford } & \text { Francis* } & \text { Francis* }\end{array}$


$\underline{\text { Table 4: Presidents appointed between } 1960 \text { and } 1975 .}$

\begin{tabular}{|c|c|c|c|c|c|}
\hline Name & $\begin{array}{l}\text { Reserve } \\
\text { Bank }\end{array}$ & Appointed & $\begin{array}{l}\text { Years } \\
\text { after PhD }\end{array}$ & Terminal degree & Institution \\
\hline Clay & Kansas & 1961 & & Law degree (NA) & Missouri \\
\hline Ellis & Boston & 1961 & $11(1950)$ & $\mathrm{PhD}$ & Harvard \\
\hline Wayne & Richmond & 1961 & & & \\
\hline Swan & San Francisco & 1961 & & BA (1932) & Berkeley \\
\hline Scanlon & Chicago & 1962 & & & \\
\hline Shuford & St. Louis & 1962 & & Law degree (NA) & S. Meth. School of Law \\
\hline Hickman & Cleveland & 1963 & $26(1937)$ & $\mathrm{PhD}$ & Johns Hopkins \\
\hline Galusha & Minneapolis & 1965 & & $\mathrm{BA}(\mathrm{NA})$ & Pennsylvania \\
\hline Patterson & Atlanta & 1965 & & Law degree (1928) & Harvard \\
\hline Francis & St. Louis & 1966 & & BA (Ag., NA) & Missouri \\
\hline Kimbrel & Atlanta & 1968 & & BA (Business, 1936) & U Georgia \\
\hline Coldwell & Dallas & 1968 & $16(1952)$ & $\mathrm{PhD}$ & Wisconsin \\
\hline Heflin & Richmond & 1968 & & Law degree (1936) & Virginia \\
\hline Morris & Boston & 1968 & $13(1955)$ & $\mathrm{PhD}$ & Michigan \\
\hline Eastburn & Philadelphia & 1970 & $13(1957)$ & $\mathrm{PhD}$ & Pennsylvania \\
\hline Mayo & Chicago & 1970 & & MBA (1938) & Washington \\
\hline MacLaury & Minneapolis & 1971 & $10(1961)$ & $\mathrm{PhD}$ & Harvard \\
\hline Winn & Cleveland & 1971 & $20(1951)$ & $\mathrm{PhD}$ & Pennsylvania \\
\hline Balles & San Francisco & 1972 & $21(1951)$ & $\mathrm{PhD}$ & Ohio State \\
\hline Black & Richmond & 1973 & $18(1955)$ & $\mathrm{PhD}$ & Virginia \\
\hline Baughman & Dallas & 1974 & & MS (Ag., 1941) & Minnesota \\
\hline
\end{tabular}


Table 5: Directors of the Board's Division of Research and Statistics, 1918-1977

\begin{tabular}{llll} 
Name & Period & Terminal degree & Institution \\
\hline Willis & $1918-1922$ & $\mathrm{PhD}(1897)$ & Chicago \\
Stewart & $1922-1926$ & $\mathrm{BA}(1909)$ & Missouri \\
Goldenweiser & $1927-1945$ & $\mathrm{PhD}(1907)$ & Cornell \\
Thomas & $1945-1949$ & $\mathrm{PhD}(1928)$ & Brookings GS \\
R. Young & $1949-1960$ & $\mathrm{PhD}(1930)$ & Pennsylvania \\
Noyes & $1960-1963$ & $\mathrm{BA}(1934)$ & Missouri \\
Brill & $1963-1969$ & $\mathrm{MA} \mathrm{(1937)}$ & Columbia \\
Partee & $1969-1974$ & $\mathrm{MBA}(1949)$ & Indiana \\
\hline Gramley & $1974-1977$ & $\mathrm{PhD}(1956)$ & Indiana \\
\hline
\end{tabular}


Table 6: Top DRS officials, 1950-1975

\begin{tabular}{|c|c|c|c|c|c|c|c|}
\hline Name & $\begin{array}{l}\text { Entered } \\
\text { Fed }\end{array}$ & Top DRS & Left DRS/Fed & $\begin{array}{l}\text { Term. } \\
\text { degree }\end{array}$ & Institution & $\begin{array}{l}\text { Entrance- } \\
\text { PhD }\end{array}$ & $\begin{array}{l}\text { Top- } \\
\text { entrance }\end{array}$ \\
\hline Garfield & 1929 & 1950 & 1966 & NA & NA & & 21 \\
\hline Robinson & $1934 ; 1956$ & 1956 & $1946 ; 1961$ & PhD (1937) & Michigan & -3 & 22 \\
\hline Burr & 1935 & 1951 & 1960 & PhD (1925) & Stanford & 10 & 16 \\
\hline Dembitz & 1935 & 1956 & 1965 & NA & NA & & 21 \\
\hline Youngdahl & 1943 & 1952 & 1954 & PhD (1949) & Minnesota & -6 & 9 \\
\hline Wernick & $1945 ; 1953$ & 1967 & $1951 ; 1974$ & BA (NA) & Emoklyn C. & & 22 \\
\hline Young & 1946 & 1946 & 1967 & PhD (1930) & Pennsylvania & 16 & 0 \\
\hline Koch & 1946 & 1955 & 1968 & NA & NA & & 9 \\
\hline Brill & 1947 & 1960 & 1969 & MA (1937) & Columbia & & 13 \\
\hline Solomon & 1947 & 1963 & 1976 & PhD (1952) & Harvard & -5 & 16 \\
\hline Sigel & 1947 & 1965 & & PhD (1953) & Harvard & -6 & 18 \\
\hline Weiner & 1947 & 1968 & 1974 & BA (NA) & Harvard & & 21 \\
\hline Noyes & 1948 & $1950 ; 1952$ & 1965 & BA (1934) & Missouri & & 2 \\
\hline Partee & $1949 ; 1962$ & 1964 & 1956 & $\begin{array}{l}\text { MBA } \\
(1948)\end{array}$ & Indiana & & 15 \\
\hline Holland & 1949 & 1961 & 1976 & PhD (1959) & Pennsylvania & -10 & 12 \\
\hline Marget & 1950 & 1950 & 1961 & PhD (1926) & Harvard & 24 & 0 \\
\hline Williams & NA & 1950 & 1974 & NA & NA & & \\
\hline Smith & 1950 & 1965 & & MA (NA) & Colorado C. & & 15 \\
\hline Wendel & 1951 & 1974 & & PhD (1966) & Columbia & -15 & 23 \\
\hline Axilrod & 1952 & 1965 & & MA (NA) & Chicago & & 13 \\
\hline Keir & 1953 & 1968 & & $\mathrm{BA}(\mathrm{NA})$ & Harvard & & 15 \\
\hline Eckert & 1953 & 1967 & & $\mathrm{PhD}$ (1947) & Cornell & 6 & 14 \\
\hline Taylor & 1953 & 1970 & 1985 & $\begin{array}{l}\text { MBA } \\
(1949)\end{array}$ & Columbia & & 17 \\
\hline Gramley & $1955 ; 1964 ; 1980$ & 1965 & $1962 ; 1977 ; 1985$ & PhD (1956) & Indiana & -1 & 10 \\
\hline Peret & 1956 & 1975 & & PhD (1962) & Harvard & -6 & 19 \\
\hline Fisher & 1958 & 1975 & & PhD (1958) & Columbia & 0 & 17 \\
\hline Garabedian & 1959 & 1970 & & MBA (NA) & American U. & & 11 \\
\hline Shull & 1965 & 1968 & & PhD (1958) & Wisconsin & 7 & 3 \\
\hline Lawrence & 1965 & 1973 & & PhD (1963) & Michigan & 2 & 8 \\
\hline Thomson & 1965 & 1974 & & PhD (1966) & Chicago (GSB) & -1 & 9 \\
\hline Zeisel & 1966 & 1969 & & PhD (1968) & American U. & -2 & 3 \\
\hline Pierce & 1966 & 1970 & 1975 & PhD (1964) & Berkeley & 2 & 4 \\
\hline Kichline & 1966 & 1974 & & PhD (1968) & Maryland & -2 & 8 \\
\hline Ettin & 1968 & 1971 & & $\mathrm{PhD}(1962)$ & Michigan & 6 & 3 \\
\hline Chase & NA & 1971 & & PhD (1960) & UC Berkeley & & \\
\hline
\end{tabular}

